\title{
Geological Characteristics and Ore-Controlling Factors of the Yazigou East Au Polymetallic Deposit in Mangya Town, Qinghai Province, China
}

\author{
Mi Xiaoming, Guan Bo, Zhang Zhiwei, Lai Sheng \\ Qinghai Fourth Institute of Nonferrous Geological Exploration, Xining, China
}

Keywords: Qinghai province, Yazigou east, Mangya town, Au polymetallic deposit, Geological characteristics, Genesis of the deposit, Ore-controlling factors

\begin{abstract}
The Yazigou East Au Polymetallic Deposit is located in the Qimantag Mountain in the western section of East Kunlun. It is adjacent to the southwestern margin of the Qaidam Basin in the north and adjacent to the Aerjinshan in the northwest. In terms of tectonics, it belongs to the Kendrick-Suhaitu-Hongmuhongcun north volcanic arc zone (third-order tectonic unit) northern Kunlun magmatic arc (second-order tectonic unit) East Kunlun arc-basin system (first-order tectonic unit). The metallogenic belt to which this deposit belongs is the East Kunlun (orogenic belt) $\mathrm{Fe}, \mathrm{Pb}, \mathrm{Zn}, \mathrm{Cu}, \mathrm{Co}, \mathrm{Au}, \mathrm{W}, \mathrm{Sn}$ and asbestos metallogenic belt. There are skarn-type Fe polymetallic deposits in the contact zone. The formation of ore bodies in the SK I, SK II skarn zones, C3-2 magnetic anomaly and C3-3 magnetic anomaly in this area is closely related to it, therefore the volcanic rock formation of the Elashan Formation and the carbonate rock formation of the Tanjianshan Formation are important indicators for searching for skarn-type polymetallic minerals in this area.
\end{abstract}

\section{Introduction}

Through the distribution characteristics of stratum, structure and magmatic rocks in the area, it is determined that the carbonate rock formation of Silurian-Ordovician Tanjianshan Formation and the volcanic rock formation of the Elashan Formation are the main ore-bearing horizons in the pre-prospected area. The skarn-type $\mathrm{Cu}-\mathrm{Fe}$ ore body and the $\mathrm{Pb}-\mathrm{Zn}$ ore body are closely related to it. The resource estimation of 15 ore bodies in the area shows that the whole area can obtain 1,370,300 tons of 334 ore. Among them, the amount of Fe ore is 1,204,300 tons, and other ore is 166, 600 tons, including 898.74 tons of $334 \mathrm{~Pb}$ ore, 579.62 tons of $\mathrm{Zn}$ ore, 751.90 tons of $\mathrm{Cu}$ ore, and 5.3 tons of Ag ore. The average grade of the deposit is TFe37.63\%, Cu 0.33\%, Ag 119.20g/t, Pb 1.12\% and Zn1.29\%. According to the summarization and analysis of the ore-controlling factors and prospecting prospects for this area in the pre-inspection, the mineralization information in this area has shown that the pre-prospected area has the prospect of searching for skarn-type polymetallic deposits and magmatic molten $\mathrm{Cu}-\mathrm{Ni}$ sulfide minerals.

\section{Regional Geological Feature}

\subsection{Stratum}

The regional stratum is mainly the Ordovician-Siliurian Tanjianshan Formation, Upper Carboniferous Diaosu Formation, Upper Triassic Elashan Formation and Quaternary (as shown in Figure 1). 


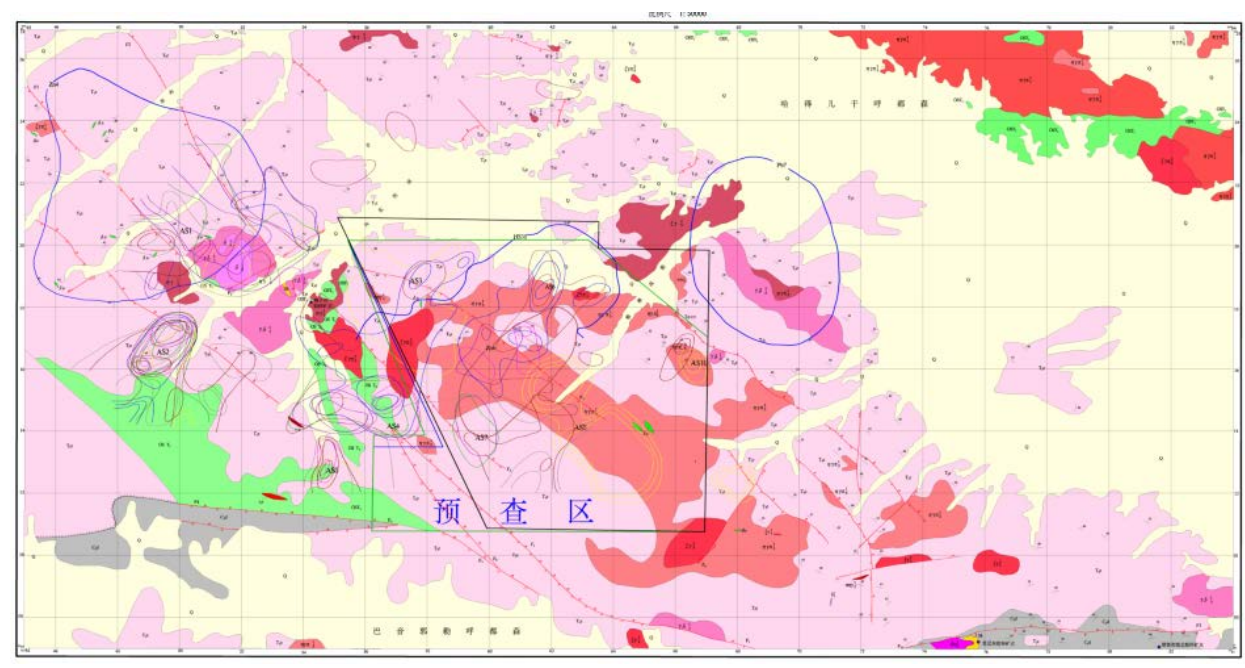

Fig.1 Regional Geological and Mineral Map of Yazigou East in Mangya Town, Qinghai Province

\subsection{Construction}

The overall tectonic lines in this area are distributed from northwest to southeast, with developed fault structures and undeveloped folds. The fault controls the distribution of regional strata and magmatic rocks. Regional faults can be divided into northwest-southeast faults, near-east-west faults, and north-east faults according to the trend (as shown in Figure 1).

\subsection{Magmatic Rocks}

The magmatic activity intrusion in the area is strong, mainly in the Indosinian acid intrusive rock mass, and the whole is distributed in a northwest strip. The surface lithology is mainly dominated by monzonitic granite porphyry and k-feldspar granite porphyry, which are in pulsating contact. In the deep part of the C3-3 magnetic anomaly in the middle of the pre-prospected area, there are hidden plaque-like biotite monzonite granites. There is also a small amount of diorite vein rock. Diorite-porphyrite veins can be seen in the deep part of the C3-3 magnetic anomaly. In addition, No.1 pyroxene rock body and olivine pyroxene rock were found in the C3-2 magnetic anomaly, the formation period is unknown.

\subsection{Metamorphic Rocks}

Metamorphic rocks are widely distributed in the area, and the rock types are complicated due to the multiple superposition of metamorphism. According to its origin, there are mainly contact metamorphic rocks and dynamic metamorphic rocks.

\section{Characteristics of Regional Ore Body}

$46 \mathrm{Cu}-\mathrm{Pb}-\mathrm{Zn}$ ore bodies have been circled in this mining area, including 18 hidden ore bodies and 9 mineralized bodies. The ore bodies are $50-260 \mathrm{~m}$ long with an average thickness of $0.64-7.25 \mathrm{~m}$. The average grade of $\mathrm{Pb}$ is $0.32-20.23 \%$, $\mathrm{Zn} 0.57-17.57 \%$, and $\mathrm{Cu} 0.23-3.89 \%$. The type is skarn, and ore minerals include galena, sphalerite, chalcopyrite, chalcopyrite, malachite, etc. The gangue minerals are mainly diopside, calcite, chlorite and garnet, followed by tremolite, quartz, potassium feldspar, and so on. The ore structure is mainly hypautomorphic-granular, with agglomerate, infested, brecciated and star-shaped structures. In terms of stratigraphy, the ore-prospecting mark is the Ordovician-Silurian Tanjian Mountain Formation. In particular, the contact zone between carbonate rocks and rock bodies is often a favorable location for the production of skarn-type ore bodies. In terms of structure, fracture zones, rock mass intrusion contact zones, wall rock bedding and fissure structures are important ore-forming structures. 


\section{Regional Minerals}

The metallogenic belt to which the area belongs is the Qimantag-Dulan variscan $\mathrm{Fe}, \mathrm{Co}, \mathrm{Cu}, \mathrm{Pb}$, $\mathrm{Zn}$, Sn, wollastonite (antimony and bismuth) metallogenic belt. It is one of the important metallogenic belts in Qinghai Province, with great prospecting potential. There are more than 30 regional deposits (spots), including ferrous and non-ferrous minerals. According to the genesis, the ferrous metals can be classified into contact-metasomatism skarn, volcano-sedimentary and sedimentary metamorphism, and a typical representative is Jingrendong Sn-Fe ore. Non-ferrous metals are $\mathrm{Cu}, \mathrm{Pb}$ and $\mathrm{Zn}$, which are mainly produced in the outer contact zone of the intrusive rock mass and skarn formed during the Indosinian and Yanshanian periods. There is also late hydrothermal mineralization, and the typical ones include the Jingrendong $\mathrm{Pb}-\mathrm{Zn}$ deposit, Yazigou $\mathrm{Pb}-\mathrm{Zn}$ deposit, Chulutaohaigaole North Pb-Zn deposit, and so on.

\subsection{Mineral Composition of Ore}

The types of ore found in the pre-prospected area are relatively simple, mainly including magnetite ore, chalcopyrite-magnetite ore, galena-sphalerite ore, etc.

\subsection{Ore Structure}

Most of the magnetite ores present allotriomorphic-irregular texture and some present hypidiomorphic-euhedral granular texture, mainly disseminated structure and followed by dense massive and irregular vein structure.

Chalcopyrite-magnetite ores mainly have an allotriomorphic-irregular texture, followed by a metasomatic texture, mainly sparsely disseminated structure and followed by massive structure and vein structure.

Gelignite-sphalerite ore present regular allotriomorphic granular texture and euhedral-hypidiomorphic granular texture, and few present metasomatic structure and disseminated structure.

\subsection{Mineral Distribution Law}

\subsubsection{Characteristics of Space Distribution}

Space distribution characteristics of minerals related to intrusive activities of intermediate-acid magma: the intrusive activity of medium-acid magma in this area is very strong; $80 \%$ of the known minerals are related to the mineralization, and the most common types of deposits are skarn deposits and hydrothermal deposits; Fe-Cu, Fe-Sn and Fe polymetallic ores are the most common mineral combinations. The skarn-type deposits mostly appear in the contact zone between the rock mass and the stratum, while the hydrothermal deposits appear in the strata away from the contact zone. The two are accompanied by production and there is a certain connection in genesis, which constitutes a series of $\mathrm{Fe}, \mathrm{Cu}$ and $\mathrm{Sn}$ polymetallic deposits related to intermediate acid intrusive rocks.

(1) Skarn-type deposits: Skarn-type deposits present characteristics of obvious belt-like distribution and segmented concentration in space. Such deposits are concentrated in the Yazigou and Chulutaohai, and the surrounding rock formations are the Tanjianshan Formation and the Diaosu Formation. The representative ones are Yazigou $\mathrm{Pb}-\mathrm{Zn}$ deposit, Chulutaohai north $\mathrm{Pb}-\mathrm{Zn}$ deposit and Jingren east $\mathrm{Pb}-\mathrm{Zn}$ deposit. The main metallogenic elements are $\mathrm{Pb}$ and $\mathrm{Zn}$, and the metallogenic scale is generally large. The skarnization is mainly in the contact zone outside the ore-bearing area, and the skarnization in the inner contact zone is weak. The shape is mostly lenticular, layer-like and irregular, and the ore body occurrence is similar to that of the contact zone and wall rocks.

(2) Hydrothermal deposits: the spatial distribution of hydrothermal deposits after the magmatic period is closely related to the medium-acid intrusive rock mass, which is mostly distributed in the contact zone of the rock mass or the rock body, and the size of deposits is small. In addition, the fault structure developed in the area is the channel and storage place for ore-bearing hydrothermal fluids, which has obvious control over the formation of hydrothermal deposits. The development of 
near-west-oriented secondary faults or intersections with north-west-directed faults is an important metallogenic section. The main metallogenic elements are $\mathrm{Cu}, \mathrm{Pb}$ and $\mathrm{Zn}$, followed by $\mathrm{Sn}$ and $\mathrm{Ag}$.

\subsubsection{Time Distribution Law}

The intrusive activities of medium-acid magma in this area were frequent, and they had been invaded from Neoproterozoic to Early Jurassic. However, the minerals related to magmatic intrusion in this area were mainly produced in the skarn in the contact zone between the Late Triassic and Early Jurassic intrusive rocks. The Late Triassic-Early Jurassic epoch is the main metallogenic period in this area. The intrusive rocks are quartz diorite, granodiorite, monzonitic granite and syenogranite. The wall rock stratum is Tanjianshan Formation, and the ore-bearing part is dominated by the skarnization zone in the contact zone. According to the ore type, it can be divided into 3 ore-forming stages. In the first stage, the minerals related to early quartz diorite and granodiorite are relatively simple. The mineral varieties is mainly dominated by $\mathrm{Fe}$, and accompanied by $\mathrm{Cu}$ and $\mathrm{Sn}$. The second stage is related to late monzonitic granite and syenogranite. The mineral varieties mainly include $\mathrm{Fe}, \mathrm{Cu}, \mathrm{Pb}$ and $\mathrm{Zn}$, with associated $\mathrm{Au}, \mathrm{Co}$ and $\mathrm{Bi}$. The third stage is related to the hydrothermal mineralization stage after the magmatic stage. The mineral varieties are mainly $\mathrm{Cu}, \mathrm{Pb}$ and $\mathrm{Zn}$ polymetallic ores, accompanied by $\mathrm{Au}, \mathrm{Co}, \mathrm{Bi}, \mathrm{Ga}, \mathrm{Ge}, \mathrm{Cd}$ and Ag.

\subsection{Mineral Generation Order and Symbiotic Combination Relationship}

The analysis of the symbiotic combination of minerals in the pre-prospected area suggests that the formation of skarn deposits in this area has experienced the skarn period and the quartz sulfide period.

(1) The skarn period

Various calcium, iron, magnesium and aluminum silicate minerals were formed during this period, and no quartz appeared. There were two stages in this period.

a) Barren stage

Rocks formed in this stage mainly include diopside, grossularite, andradite as well as a small amount of idocrase, anorthose and potassium feldspar.

b) Magnetite stage

This stage is marked by the formation of a large amount of magnetite, and it is also the main stage of magnetite formation in this area. Magnetite is mainly composed of diopside, andradite and grossularite. In addition to a large amount of magnetite enrichment, epidote, actinolite and tremolite were also formed at this stage.

(2) Quartz sulfide period

a) High-temperature stage

At this stage, quartz appeared, and a large amount of hydrous silicate minerals were produced, mainly including tremolite, actinolite, ordinary hornblende, ordinary pyroxene, epidote and biotite. A small amount of pyrite and pyrrhotite were also produced.

b) Medium-temperature stage

This stage is marked by the formation of a large number of metal sulfides, mainly including pyrrhotite, pyrite, chalcopyrite, sphalerite, galena, etc. Although the above-mentioned metal sulfides are products of the same period, they have differences in terms of crystallization time: pyrite, pyrrhotite and chalcopyrite were formed earlier, while sphalerite and galena were later. In this stage, the gangue minerals such as chlorite, quartz and mica were produced in large quantities.

c) Low-temperature stage

A large amount of chlorite, quartz, etc. are generated in this stage.

According to the analysis above, the formation order of metal minerals in this area is: magnetite $\rightarrow$ pyrite, pyrrhotite and chalcopyrite $\rightarrow$ sphalerite and galena.

\subsection{Genesis of the Deposit}

In the Indosinian period, acid magmatic intrusive rock masses had frequent magmatism in this area. The lithology is mainly monzonitic granite porphyry, feldspar porphyritic granite and 
porphyritic biotite monzonite granite, etc. They are the main parent rocks of mineralization in the area, providing thermal power and source for most of the mineral formation in the area. The ore-forming wall rocks are carbonates of the Ordovician-Siliurian Tanjianshan Formation and the Late Triassic Elashan Formation volcanic rocks.

In the Indosinian acid rock body, the secondary fault structure is a channel and storage place for ore-bearing hydrothermal fluids, and $\mathrm{Pb}-\mathrm{Zn}$ deposits were formed at the secondary fault location. This type of deposits is the hydrothermal deposits.

The contact zones between the Indosinian acid rock mass and the Ordovician-Siliurian Tanjianshan Formation carbonate and the Late Triassic Elashan volcanic rock group is important parts of the formation of skarn and is accompanied by the production of magnetite, chalcopyrite, sphalerite, galena, auriferous ores, etc. Wall rock alteration is dominated by skarnization, and the ore bodies are constrained by the characteristics of magmatic rocks and the composition and structure of the surrounding rock. The formation of the deposits has experienced the mineralization stage of general skarn deposits, and they are contact metasomatic deposits.

A Cu-Ni mineralized body was found in the No. 1 pyroxene rock body, and it belongs to the type of magmatic liquation. Because of the low level of research on this type of deposits, there is insufficient understanding of their causes.

\section{Ore-Controlling Factors}

\subsection{Skarn Deposit}

In this area, Indosinian acid rock masses, limestones and marbles of Tanjianshan Formation and crystallographic rhyolitic tuffs of Elashan Formation are the main ore-controlling factors for the formation of skarn-type iron polymetallic ore bodies, and the development of fissure structure is a favorable geological condition for skarn-type iron polymetallic mineralization.

\subsection{Hydrothermal Deposit}

In this area, this type of deposits is closely related to the Indosinian acid intrusive rock mass. The developed secondary tensional fault structure was the channel and storage place for ore-bearing hydrothermal fluids, and had an obvious control effect on the formation of hydrothermal deposits. The secondary fault zone developed in the area is an important metallogenic zone.

\subsection{Magma Liquation}

For this type of deposits, basic-ultrabasic rock mass is the most important ore-controlling factor. The ore body exists directly in the rock body, and the size of the rock body determines the size of the deposit. In addition, the degree of differentiation of the rock mass is also a relatively important factor. The larger the crystalline particles of pyroxene are, the more beneficial it is to the formation of the deposit.

\section{Conclusion}

1) According to the distribution characteristics of stratum, structure and magmatic rock in the area, it can basically be confirmed that the Late Triassic Elashan volcaniclastic rock group and the Silurian-Ordovician Tanjianshan carbonate rock group are the main ore-bearing bed in the pre-prospected area. Among them, the iron-copper ore body in the SK I skarn zone and the V-1Fe ore body in the C3-3 magnetic anomaly are in the crystallographic rhyolitic tuff of the Elashan Formation; the formation of polymetallic ore bodies in the SK II skarn zone and the V-2Fe and $\mathrm{V}-2 \mathrm{Fe}$ ore bodies in the C3-3 magnetic anomaly are closely related to the carbonate rock group of the Tanjianshan Formation.

2) There are 2 skarn belts and 1 broken alteration zone in the area, and a total of 15 ore bodies and one Cu-Ni mineralized body were circled. The ore bodies are $100-383 \mathrm{~m}$ long and $1.36-10.87 \mathrm{~m}$ thick. The average grade of the TFe ore body is $20.81-46.59 \%$, with the highest single sample being $62.15 \%$. The average grade of $\mathrm{Cu}$ is $0.30-0.77 \%$, with the highest single sample being $0.94 \%$. The 
average grade of $\mathrm{Pb}$ is $0.39-1.92 \%$, with the highest single sample being $5.96 \%$. The average grade of $\mathrm{Zn}$ is $0.6-1.66 \%$, with the highest of single sample being $2.99 \%$. The average grade of $\mathrm{Ag}$ is $35.2-138 \mathrm{~g} / \mathrm{t}$, with the highest of single sample being $466 \mathrm{~g} / \mathrm{t}$. The $\mathrm{Cu}-\mathrm{Ni}$ mineralization is $79 \mathrm{~m}$ long, and the apparent thickness is $1.74 \mathrm{~m}$. Ni grade is $0.16-0.21 \%$, Co $0.01-0.014 \%$ and $\mathrm{Cu} 0.12 \%$.

3) After the resource estimation of 15 ore bodies in the pre-prospected area, the whole area is predicted to contain 1,370,300 tons of 334 ore. Among them, the amount of Fe ore is 1,204,300 tons, and that of other ore is 166,000 tons, including 898.74 tons of $334 \mathrm{~Pb}$ ore, 579.62 tons of $\mathrm{Zn}$ ore, 751.90 tons of $\mathrm{Cu}$ ore, and 5.3 tons of $\mathrm{Ag}$ ore. The average grade of the deposit is: $\mathrm{TFe} 37.63 \%, \mathrm{Cu}$ 0.33\%, Ag 119.20g/t, Pb 1.12\% and Zn 1.29\%.

4) The mineralization information in this area has indicated that the pre-prospected area has the prospect of searching for skarn-type iron polymetallic ore and magmatic molten $\mathrm{Pb}-\mathrm{Ni}$ sulfide minerals.

\section{Acknowledgment}

This research was financially supported by Pre-inspection of the Yazigou East Au Polymetallic Deposit in Mangya Town, Qinghai Province belongs to QDDK [2018] 130 by Department of Natural Resources of Qinghai Province

\section{References}

[1] Liu Jiannan, Feng Chengyou, et al. Metallogenization Characteristics and Resource Potential Analysis of East Kunlun Metallogenic Belt [J]. Acta Geologica Sinica, 2016(07): 1364-1376

[2] Zhang Daming, Su Xuliang, et al. Metallogenic Characteristics and Prospecting Target of Ketinghaer Porphyry Copper-molybdenum deposit in Easten Kunlun Mountain Rang [J]. Mineral Exploration, 2016(05): 705-710

[3] Su Xuliang, Zhao Yongliang, et al. Prospecting thinking and model and model for the Ketinghaer porphyry copper molybdenum deposit in East Kunlun Mountains [J]. Geology in China, 2014(06): 2048-2062

[4] Ma Shenglong, Zhang Peiqing and Zhang Yongsheng. Characteristics and application of primary halo in Changshan porphyry molybdenum deposit [J]. Environment and Life, 2014(16)

[5] Yi Liwen, Lu Anhuai, Gu Xiangping and Lei Hao. Ore Mineralogical Characteristics of the Main Deposits in the Qimantag Iron-copper Polymetallic Metallogenic Belt of East Kunlun [J]. Acta Mineralogica Sinica, 2013(S2) 